\title{
Berderma dan Sejarah Sosial Politik Islam Indonesia
}

\section{MUKHLIS RAHMANTO}

Dosen di Jurusan Muamalah (Ekonomi dan Perbankan Islam), Fakultas Agama Islam, Universitas Muhammadiyah Yogyakarta. Email: mukhlisindunisi@gmail.com

Judul buku : Faith and the State: A History of Islamic Philanthropy in Indonesia

Penulis : Amelia Fauzia

Penerbit : Brill, Leiden

Kota : Belanda

Tahun : 2013

Tebal : : 346

Bentuk-bentuk kedermawanan seperti zakat, infak, sedekah dan wakaf atau sekarang lebih populer dengan istilah filantropi Islam, adalah jantung dari ajaran Islam itu sendiri, yaitu rukun iman yang lima. Praktik dari bentuk kedermawanan ini dalam sejarah Islam, membuktikan bahwa Islam dalam doktrin normatifnya, adalah agama yang menekankan kesalihan sosial yang berujung pada keadilan sosial. Di sinilah cita-cita sosial Islam menjadi sebuah keniscayaan. Keimanan seorang muslim tidak dapat dinilai sempurna, jika hanya salih (baik) terhadap Tuhannya, namun juga diukur dari kepedulian sosialnya terhadap manusia lain. Ukuran ini termaktub tegas dalam Al-Qur'an dan Hadis, salah satunya adalah perintah memelihara anak yatim dan memberi makan fakir miskin dalam surat Al-Ma'un. Akan tetapi, dinamika praktik kedermawanan di lingkup umat Islam, tidak terlepas dari bermacam kepentingan yang ada dan berkelindan, apalagi ketika Islam sebagai ajaran dari Tuhan dipraktik-ekspresikan, terkait dan masuk dalam bingkai kekuasaan, dalam hal ini adalah negara yang mempunyai otoritas mengatur suatu wilayah tertentu. Meski kebanyakan tesis menunjukan, secara umum pengelolaan filantropi lebih banyak bertumpu dan diperankan oleh masyarakat sipil. Dari titik kisar inilah, buku ini lahir dan merefleksikan kontestasi (persaingan) antara individu (iman-faith) dengan negara (state). 
Dalam hal ini, kajian sejarah sosial Islam di Indonesia mendapat tambahan referensi, dengan hadirnya buku yang aslinya adalah penelitian doktoral yang dilakukan oleh Amelia Fauzia, -dosen dan peneliti di Universitas Islam Negeri Syarif Hidayatullah- di Universitas Melbourne, Australia, di bawah bimbingan Prof. M.C Ricklefs. Pembaca disuguhi tidak hanya dinamika sejarah filantropi Islam di Indonesia, akan tetapi juga perkembangan pemaknaan dan manifestasi terhadap konsep filantropi Islam oleh para ulama dan intelektual muslim, yang banyak terekam dalam turats (legasi) fikih klasik. Amelia juga mengawali dengan mengetengahkan bahasan tradisi dan praktik filantropi di dunia Islam secara umum, dengan bahasan khusus umat Islam di Mesir dalam mengelola zakat dan wakaf, yang direpresentasikan oleh Al-Azhar, sebuah institusi dakwah dan pendidikan Islam Sunni tertua yang mampu bertahan seribu tahun lebih dengan topangan dana filantropi Islam.

Buku ini terdiri dari empat bab yang terinci ke dalam tujuh bagian. Penulis kemudian membagi babak sejarah filantropi Islam di Indonesia menjadi tiga: pertama, masa awal Islam masuk ke Indonesia hingga era kerajaan-kerajaan Islam; kedua, masa kolonialisme hingga pra-kemerdekaan; ketiga, era kemerdekaan, Orde Baru hingga reformasi.

Babak pertama pada masa awal Islam masuk ke Indonesia hingga era kerajaan-kerajaan Islam, temuan Amelia menunjukan, bahwa filantropi Islam dalam bentuk zakat dan wakaf lebih dijadikan sebagai sarana mendukung Islamisasi dan belum banyak diatur oleh negara. Artinya, dari sisi administrasi, filantropi Islam berjalan begitu saja, ada atau tidak perhatian dan regulasi dari kesultanan, yang jika ditelisik lebih mengutamakan pajak. Hal itu dapat dilihat pada dokumen Undang-Undang Melaka, sebagai regulasi legal yang banyak dipakai oleh kesultanan-kesultanan Islam Sumatra sepanjang selat Melaka. Sedang proses Islamisasi di sini diwakili, salah satunya dalam bentuk patronase antara para pemuka agama dengan umatnya. Filantropi Islam dinilai menguatkan posisi para pemimpin agama dalam melaksanakan Islamisasi, dikarenakan menariknya, umat tidak banyak memiliki pengetahuan mengenai zakat, bagaimana dan kepada siapa harus disalurkan.

Babak kedua pada masa kolonialisme, Amelia menyimpulkan bahwa kolonialis, dalam hal ini Belanda, sebagai penguasa Nusantara tidak terlalu berambisi ikut campur mengurus wilayah filantropi Islam, karena dikhawatirkan memunculkan resistensi atau perlawanan dari umat Islam yang mayoritas. Keadaan ini memberi kesempatan pengelolaan filantropi Islam dilakukan oleh masyarakat sipil (umat Islam sendiri), sebagaimana dicontohkan oleh 
Muhammadiyah, yang membidani ide dan praktik pengelolaan serta manajemen dana filantropi, untuk mewujudkan perubahan sosial di masyarakat, bukan negara, karena penguasa saat itu adalah Belanda. Amelia mengetengahkan beberapa fakta sejarah yang unik, dimana seyogyanya bagi generasi baru kalangan Islam modernis dewasa ini, memberikan pelajaran penting bagaimana generasi awal Muhammadiyah melakukan intepretasi dan manifestasi filantropi Islam. Fakta unik itu salah satunya, bagaimana ideologi terbuka (inklusif) mendasari pengelolaan filantropi ala Muhammadiyah masa itu, yang memang gagasan Muhammadiyah dalam hal ini, terinspirasi oleh lembaga kedermawanan (charity) Kristen yang telah terlebih dahulu muncul dan berkembang, khususnya di Yogyakarta sebagai tempat kelahiran Muhammadiyah. Rumah sakit atau klinik milik Muhammadiyah sebagaimana tertuang dalam Anggaran Dasarnya didirikan untuk melayani setiap golongan, agama, dan masyarakat berlatar-belakang apapun. Juga menerima donasi filantropi dari siapapun, tanpa melihat latar belakangnya. Bahkan beberapa doktor Belanda pun ikut membantu pelayanan medis. Selain itu, ide pelembagaan filantropi yang digagas oleh Muhammadiyah sebagai gerakan modernis Islam, mendapat resistensi dari kalangan tradisionalis yang kukuh berpendapat, bahwa pelembagaan filantropi Islam akan mengurangi pendapatan para ulama dari umat sebagai klien mereka. Dalam hal ini, kontestasi pengelolaan dana filantropi Islam pun berlangsung di lingkaran masyarakat sipil Islam itu sendiri.

Babak ketiga yaitu era kemerdekaan, Orde Baru, hingga reformasi. Pasca kemerdekaan, para intelektual Islam, terutama kalangan modernis, banyak tertarik membahas dan mengembangkan isu dan wacana filantropi, sehingga melahirkan beberapa lembaga pendidikan tinggi Islam yang dibiayai dari dana filantropi sekaligus untuk kepentingan Islamisasi. Masalahnya, tidak hanya para intelektual yang tertarik, negara dalam hal ini pemerintahan Orde Baru juga tertarik untuk mengelola zakat dengan menimbang-kalkulasikan keuntungan ekonominya, terutama untuk menopang pembangunan yang membutuhkan banyak modal dana. Negara dalam hal ini sangat mendukung, dimana menurut Amelia, juga karena faktor balas budi terhadap umat Islam yang membantu negara dalam menghadapi gerakan komunisme. Tahun 1968, Badan Amil Zakat (BAZ) pusat resmi berdiri menyusul di tingkatan provinsi hingga 1985. Dalam perjalanannya, BAZ ternyata tidak berjalan mulus dan mendapat banyak resistensi, terutama dari pegawai negeri sipil muslim yang tidak punya pilihan lain, akan pemotongan gaji dan penyalurannya yang dilakukan oleh beberapa yayasan milik Suharto, salah satunya Yayasan Amal Bakti Muslim 
Pancasila. Dan jelas dalam hal ini, hal itu dilakukan, utamanya untuk mendukung citra politik Suharto di mata umat Islam serta demi kelanggengan rezim Orde Baru. Perlawanan lain datang dari kalangan tradisionalis, apalagi setelah BAZ didirikan di tingkatan desa, dengan alasan sama, terkikisnya hubungan kuat patron antara pemimpin agama dan umatnya yang diikat oleh dana filantropi. Lebih lanjut, pada masa ini negara sangat antusias mengelola dana filantropi Islam, sehingga masyarakat sipil Islam menjadi lemah, namun tetap ditemukan siasat dan langkah yang diambil oleh masyarakat sipil Islam dalam rangka mensiasati kebijakan dan regulasi dari negara.

Masa reformasi yang ditandai dengan desentralisasi, menandakan kekuasaan negara yang melemah. Oleh karena itu, masyarakat sipil Islam terutama dari kalangan modernis dan revivalis (kelompok yang menekankan Islam dipraktikan di semua bidang kehidupan termasuk politik), berperan banyak dalam mendirikan lembaga filantropi Islam yang bertujuan, menurut temuan Amelia, untuk mendukung Islamisasi yang lebih luas. Di sinilah terjadi tarik ulur kepentingan hingga persaingan (kontestasi) dan memunculkan dilema, dimana negara tidak ingin kehilangan posisinya, sementara lembagalembaga filantropi Islam menginginkan misinya tercapai. Hal itu terbukti dengan uji materi yang dilakukan berkali-kali oleh konsorsium lembaga-lembaga amil zakat untuk Undang-Undang No. 23/2011 tentang manajemen zakat yang telah disahkan oleh parlemen. Dalam penelisikan yang lebih umum, memang Amelia sangat banyak menemukan alur dan menggunakan argumen 'Islamisasi' dalam praktik sejarah filantropi Islam di Indonesia. Penggunaan argumen ini, hemat penulis, patut dipertanyakan kembali seiring dengan makin inklusifnya institusi-institusi pengelola filantropi Islam di Indonesia dewasa ini, dimana hal itu dapat dilihat dalam program-program yang direncanakan, yang menawarkan pemberdayaan zakat misalnya, di masyarakat, untuk kepentingan ekonomi, sosial dan kemanusiaan bagi kepentingan kelompok miskin dan tidak mampu, tanpa mempertimbangkan latar belakang agama sekalipun, sebagaimana temuan Asep Saipudin Jahar (2015).

Dari kesemuanya, buku ini sangat menarik dan memberikan alur optimisme, bahwa dana filantropi Islam (zakat, infak, sedekah, dan wakaf) mempunyai beberapa fungsi sosial di antaranya: mengkonsolidasikan solidaritas sosial; sarana memenuhi jaminan sosial dan sarana memenuhi kebutuhan serta fasilitas publik. Filantropi Islam memainkan perang penting dalam sejarah sosial Islam di Indonesia, sebagai sumber pendanaan dari dan untuk masyarakat sipil Islam serta berimplikasi menyasar umat lain dalam lingkup yang lebih 
luas. Dengan atau tanpa negara, masyarakat sipil Islam di Indonesia mampu mempertahankan eksistensinya. Terakhir, studi yang dilakukan oleh Amelia, menguatkan tesis yang sebelumnya telah muncul dan mapan terkait dengan praktik filantropi di berbagai belahan dunia, yaitu: weak state, strong philanthropy; strong state, weak philanthropy (jika negara lemah, maka filantropi menguat dan jika negara kuat, maka filantropi melemah). 